${ }^{3}$ Leek, A E, and Chard, T, Alpha fetoprotein, ed R Masseyeff, p 563. INSERM, Paris, 1974

${ }^{4}$ Keyser, J W, Kohn, J, and Milford Ward, A, Lancet, 1976, 1, 1015.

${ }^{5}$ Horacek, I, et al, Lancet, 1976, 2, 200.

Harwood, L M, Journal of Medical Laboratory Technology, 1962, 19, 19.

7 Batstone, G F, Blair, A W, and Slater, J M, Handbook of Prenatal Paedia- trics for Obstetricians and Paediatricians. Aylesbury, Medical and Technical Publishing Co, 1971.

${ }^{8}$ Brock, D J H, Lancet, 1975, 2, 495.

9 Stewart, C R, unpublished.

\section{Summary}

Twelve separate outbreaks of confirmed cowpox, 10 involving humans, were reviewed. Six of the patients, including three children, had severe infections and five were admitted to hospital. In three outbreaks both people and cows were affected but it was not known how the infections entered the herds. In seven outbreaks no direct contact with cattle was established and clinical and serological examination failed to show evidence of cowpox in the bovine population.

Comparison of these data with information about infections known to be enzootic in cattle leads to the suggestion that cows are not the natural reservoir of cowpox. This should be remembered when diagnosis is considered. The role of small wild animals as hosts and vectors of "cowpox" should be investigated.

\section{Introduction}

The success of the World Health Organisation's Smallpox Eradication Campaign has aroused interest in the epidemiology of those poxviruses, immunologically related to smallpox virus, that infect man. Accidental infection with vaccinia, virus should reduce as vaccination is discontinued. Of the other virus infections concerned only cowpox is indigenous to Britain and likely to be a public health hazard.

Department of Medical Microbiology, Liverpool University, Liverpool L69 3BX

DERRICK BAXBY, BSC, PHD, lecturer
Cowpox virus infection is reported in Britain only when human cases occur or when many cattle are affected. Human cowpox has usually been regarded as an occupational disease of dairy farmworkers. ${ }^{1-3}$ A recent note, ${ }^{4}$ however, discusses three separate cases in man in which contact with cattle was not established. Perhaps because cowpox is relatively unimportant no studies have been made on the way in which the virus is maintained and transmitted. Some suggest that cowpox is enzootic in cattle and that it is maintained by trivial infection. ${ }^{3}$ Others consider cowpox to be uncommon or rare but do not suggest how the virus is maintained. ${ }^{5-7}$

All the above workers assume that the cow is the natural host and reservoir of cowpox virus, although the possibility that some unknown wild mammal or bird may be the reservoir has been raised. ${ }^{8}{ }^{9}$ Cowpox virus is not particularly resistant and would not survive for long in the soil. Several biotypes of cowpox virus are in circulation, ${ }^{1011}$ and enzootic infection in some species is necessary to ensure the survival of these biotypes.

This paper reviews 12 separate cases of confirmed cowpox infection occurring in 1965-76, 10 of them in man, in an attempt to provide information on the natural history of the disease. The biological properties of some of the isolates have already been described $;^{10} 11$ the remainder will be described elsewhere.

Cowpox is not notifiable and farmers are not obliged to allow examination of their animals. Such information as is available has been obtained through the willing co-operation of farmers and patients and the medical and veterinary workers listed at the end of this paper.

\section{Outbreaks}

Some information on the incidents is listed in table I. There was no connection between them, and they occurred in different places at different times. For convenience each incident is referred to as

TABLE I-Some details of the 12 outbreaks reviewed

\begin{tabular}{|c|c|c|c|c|c|c|c|c|}
\hline \multicolumn{3}{|c|}{ Outbreak } & \multirow{2}{*}{$\begin{array}{c}\text { Cows } \\
\text { infected }\end{array}$} & \multicolumn{5}{|c|}{ Human cases } \\
\hline No & Place & Year & & $\begin{array}{c}\text { Farm } \\
\text { worker }\end{array}$ & Age* & Lesions & $\begin{array}{l}\text { Days in } \\
\text { hospital }\end{array}$ & Vaccinated \\
\hline $\begin{array}{r}1 \\
2 \\
3 \\
4 \\
5 \\
6 \\
7 \\
8 \\
9 \\
10 \\
11 \\
12\end{array}$ & $\begin{array}{l}\text { Tyson (N Wales) } \\
\text { "188" (Somerset) } \\
\text { Dorchester } \\
\text { Winchester } \\
\text { Middlesbrough } \\
\text { Exeter } \\
\text { Burnley } \\
\text { Penrith } \\
\text { Scarborough } \\
\text { Lincoln } \\
\text { Bristol } \\
\text { Taunton }\end{array}$ & $\begin{array}{l}1965 \\
1968 \\
1969 \\
1969 \\
1971 \\
1971 \\
1974 \\
1974 \\
1975 \\
1975 \\
1976 \\
1976\end{array}$ & $\begin{array}{l}+ \\
+ \\
+ \\
- \\
+ \\
= \\
= \\
- \\
+\end{array}$ & $\begin{array}{l}\overline{-} \\
\overline{+} \\
\bar{z} \\
+ \\
\bar{z} \\
\bar{z} \\
\bar{z} \\
\overline{+}\end{array}$ & $\begin{array}{r}- \\
\text { A } \\
\text { A } \\
8 \\
\text { A } \\
14 \\
\text { A } \\
6 \\
17 \\
17 \\
\text { A }\end{array}$ & $\begin{array}{l}\quad \overline{-} \\
\text { Hand } \\
\text { Hand } \\
\text { Chin } \\
\text { Hand } \\
\text { Hand, chin } \\
\text { Hand } \\
\text { Face } \\
\text { Hand } \\
\text { Face } \\
\text { Hand }\end{array}$ & $\begin{array}{l}\bar{Z} \\
\overline{24} \\
\frac{7}{21} \\
17 \\
\frac{8}{-}\end{array}$ & $\begin{array}{l}\bar{z} \\
\bar{z} \\
\bar{t} \\
\overline{-}\end{array}$ \\
\hline
\end{tabular}

- $A=$ Adult. Figures give age in years.

A = Adult. Figures give
+ Vaccinated in infancy. 
an "outbreak," although in some only one human case occurred. Outbreaks 1 and $2^{9}$ involved cows only.

Five of the outbreaks $(1-3,6,12)$ fitted the presumed typical description of cowpox in that cattle were infected. In three of these $(3,6,12)$ farm workers were also infected. Inquiries into the circumstances surrounding these outbreaks did not show how the herds became infected. Cowpox was not detected in neighbouring herds and no subsequent cases occurred. In most cases there had been no contact with neighbouring cattle. A limited serological survey of cattle in the vicinity of outbreak 6 failed to detect animals with antibody (see below and table II).

TABLE II-Survey of bovine serum samples for virus neutralising antibody

\begin{tabular}{|c|c|c|c|c|c|c|c|}
\hline \multirow{2}{*}{$\begin{array}{c}\text { Source } \\
\text { (Outbreak No) }\end{array}$} & \multirow{2}{*}{$\begin{array}{l}\text { No } \\
\text { tested }\end{array}$} & \multicolumn{6}{|c|}{ Antibody titre* } \\
\hline & & $<10$ & -20 & -40 & -80 & $>80$ & $\begin{array}{c}\text { No } \\
\text { positive }\end{array}$ \\
\hline $\begin{array}{ll}\text { Exeter (6) } & \ldots \\
\text { Lancashire (random) } & \\
\text { Burnley (7) } & \ldots \\
\text { Cumbria (random) } & \ldots \\
\text { Penrith (8) } & \ldots \\
\text { Scarborough (9) } & \ldots\end{array}$ & $\begin{array}{r}63 \\
200 \\
200 \\
222 \\
315 \\
76\end{array}$ & $\begin{array}{r}59 \\
194 \\
194 \\
217 \\
309 \\
74\end{array}$ & $\begin{array}{l}4 \\
3 \\
6 \\
2 \\
5 \\
2\end{array}$ & $\begin{array}{l}0 \\
0 \\
0 \\
3 \\
0 \\
0\end{array}$ & $\begin{array}{l}0 \\
2 \\
0 \\
0 \\
1 \\
0\end{array}$ & $\begin{array}{l}0 \\
1 \\
0 \\
0 \\
0 \\
0\end{array}$ & $\begin{array}{l}0 \\
3 \\
0 \\
3 \\
1 \\
0\end{array}$ \\
\hline Total & 1076 & 1047 & 22 & 3 & 3 & 1 & 7 \\
\hline
\end{tabular}

*Figures give reciprocal of serum dilution permitting 50 "., virus survival after 2 hours at $37^{\circ} \mathrm{C}$. Values $>20$ were regarded as positive.

Seven of the human infections were particularly interesting in that detailed inquiries failed to establish direct contact with cattle, although all the patients lived in, or had visited, rural areas. One patient was a veterinary surgeon's receptionist (4), who presumably was infected while cleaning instruments. Two were people who had visited farms $(7,11)$, two were from farming families $(5,8)$, and one (10) possibly became infected while blackberrying.

Although these people may have been infected from cattle indirectly, detailed inquiries again failed to detect any evidence of recent bovine cowpox in these localities. In addition serological surveys failed to detect any evidence of recent infection in cattle. No further cases were reported. Three of the patients $(5,7,9)$ were children, and two others were only 17 years old $(10,11)$.

\section{Clinical features}

In most of the outbreaks in which both human and bovine cases occurred a diagnosis of cowpox was considered at an early stage. In the others cowpox was not usually suspected until two to three weeks after presentation and when initial clinical diagnoses were not confirmed. Two patients (cases 8 and 9) were initially thought to have orf and accidental vaccination respectively. Anthrax was initially diagnosed in cases 10 and 11 , and although cowpox was suspected in case 5 specific steps were taken to exclude anthrax. In all cases the correct diagnosis was confirmed by virus isolation.

Six of the 10 patients had lesions on the hand only, three on the chin or face only, and one on both face and hand (table I). In most cases there was local oedema, lymphadenitis, and pyrexia and in case 7 considerable cellulitis. ${ }^{4}$ In four cases $(4,10-12)$ infection was not particularly severe. In the remaining cases infection was severe and four patients $(5,7-9)$ were admitted to hospital for seven to 24 days; the remaining two $(3,6)$ were absent from work for several days. One patient (case 10), who was originally thought to have anthrax, was admitted to hospital as a precautionary measure only and retained for reasons not connected with the infection.

As far as could be determined only one of the patients, an adult, had ever received smallpox vaccination, and that in infancy.

\section{Serological survey}

Bovine serum samples were screened for virus neutralising antibody using a standard test. ${ }^{12}$ In addition to samples from the immediate vicinities of outbreaks 6-9 samples were also available from the general areas in which outbreaks 7 and 8 occurred. Since occasional known negative bovine serum samples from, for example, university herds, will neutralise virus non-specifically at up to $1 / 10$, only samples with titres of $1 / 20$ and above were regarded as positive. Of the 1076 samples tested only 22 had titres of $1 / 10$ to $1 / 20$, and only seven, all from different herds, had titres over $1 / 20$. Of these, six had low titres (table II) and the remaining sample had a titre of $1 / 90$. None of these samples inhibited cowpox haemagglutinin in a haemagglutinininhibition (HAI) test. With other poxvirus infections a positive HAI test is usually regarded as indicating recent infection. ${ }^{2}{ }_{13}$ These seven animals had possibly been infected with cowpox at some time in the past but no information on this was available.

Tests on samples from individual animals infected in outbreaks 2 and 12 showed high levels of neutralising antibody (1/1000) and significant levels $(1 / 32-1 / 64)$ of HAI antibody, as would be expected of convalescent animals.

These results failed to indicate the source of the human cases concerned. More significantly, they cast doubt on the supposition that cowpox is enzootic in British cattle.

\section{Discussion}

The clinical features of these cases suggest that human cowpox may be rather more severe than other accounts suggest. ${ }^{12}$ This may be due to the lack of specific immunity and the fact that some of the severe infections were in children; this last feature is itself interesting.

The main point of interest, however, concerns the sources of the various outbreaks. The close association between human and bovine cowpox is shown by the three outbreaks in which both human and bovine cases occurred. But each outbreak was an isolated incident and no evidence was obtained to indicate how the infections entered the herds. More significantly, in seven of the human cases no direct contact with cattle was established. In particular no cases of bovine cowpox were detected in the vicinities of these human cases, and serological surveys failed to detect the number of animals with significant levels of antibody, which one would expect if cowpox was enzootic in cattle. Indirect infection from cattle was therefore unlikely, and none of the patients had been away from home at the time infection occurred.

Human cowpox is sufficiently severe for medical aid to be sought and cases in man are unlikely to be missed. Nevertheless, cases are reported only once or twice a year and the absence of cowpox in abattoir workers has been noted. ${ }^{8}$ In contrast, studies on bovine herpes mammillitis have shown that $19.5^{\circ} \%$ of 400 cattle randomly selected in south-west England had antibody to the virus, ${ }^{14}$ which is also enzootic in other areas. ${ }^{15}$ Paravaccinia virus (morphologically and antigenically distinct from cowpox) was identified in 15 out of 16 herds in Dorset, ${ }^{16}$ 20 herds in south-west England, ${ }^{17}$ and in $13^{\circ}$ o of 358 animals examined in abattoirs in Somerset. ${ }^{17}$ These extensive surveys showed only one isolated outbreak of cowpox (outbreak 2). ${ }^{9}$ During 1975-6 84 human cases of paravaccinia/orf were reported, at least 11 of them in abattoir workers. ${ }^{18}$

This information on diseases known to be enzootic in cattle provides a striking contrast to the data available on cowpox. Relevant information also comes from recent studies in Russia. A virus, closely-related to cowpox virus, caused a serious epizootic in the Felidae (lions, cheetahs, etc) in Moscow Zoo. ${ }^{19}$ Subsequent surveys indicate that the virus is enzootic in wild gerbils, which probably represent the reservoir (S S Marennikova, personal communication).

From this evidence it is reasonable to argue that cows are not the natural host and reservoir of "cowpox" virus but that cows and humans both become infected accidentally, cows from the reservoir and man from either the cows or the reservoir. Human infection from the reservoir would probably be indirect. The reservoir might be some small wild mammal. ${ }^{8}$ The restriction of cowpox to Britain and Western Europe ${ }^{3}$ suggests that birds are unlikely to be implicated. It is not known whether cows have ever been the reservoir of cowpox virus. Jenner and the early vaccinators had certain difficulties in obtaining fresh vaccine stocks.

A possible diagnosis of cowpox should be considered in people, particularly children, presenting with appropriate symptoms even though contact with cattle is not suspected 
or proved. It is hoped that more detailed inquiries into future cases will help to identify the reservoir. A close relation between cattle and badgers is indicated by studies on bovine tuberculosis, ${ }^{20}$ and farmers' tales link cows and hedgehogs-frequent visitors to rural gardens. Preliminary surveys of the available wild animal material have, however, so far failed to provide useful information.

I thank the following for so willingly providing material from and information about the outbreaks indicated: J Nagington $(6,8,10)$; M S Pereira (3-5); A D Osbourne $(2,11,12)$; P Higgins and S Clarke $(11,12)$; J D Tyson (1); E P J Gibbs (2); G Tee (3); J Taylor (4); P R Mortimer, D Helbert, J Harbourne (5); R J C Hart, B Marsden, I H Fincham (6); D N Hutchinson, $\mathrm{N} D$ Noah, A Maguire, $\mathrm{N} \mathrm{H}$ Brooksbank (7); D G Davies, D F Collings (8); M H Hambling, E Evans, A Bogdan, G W Thomas (9); J G Wallace (10); J V S Pether (12). I also thank Professors A W Downie and K McCarthy for many stimulating discussions.

\section{References}

1 Downie, A W, British Medical fournal, 1951, 2, 251.

2 Downie, A W, and Kempe, C H, in Diagnostic Procedures for Viral and Rickettsial Infections, $\mathrm{p} 281$. New York, American Public Health Association, 1969.
3 Dekking, F, in Zoonoses, p 411 . Amsterdam, Elsevier, 1964.

${ }^{4}$ British Medical Fournal, 1975, 1, 46.

${ }^{5}$ Miller, W L, and West, G P, Black's Veterinary Dictionary, 9th edn. London, Black, 1970.

${ }^{6}$ Lauder, I M, et al, Veterinary Record, 1971, 89, 571.

7 Blood, D C, and Henderson, J A, Veterinary Medicine, 4th edn. London, Ballière and Tindall, 1974.

${ }^{8}$ Dixon, C W, Smallpox. London, Churchill, 1962.

9 Gibbs, E P J, Johnson, R H, and Collings, D F, Veterinary Record, 1973, 92, 56.

10 Baxby, D, Veterinary Record, 1975, 96, 388.

11 Baxby, D, Zentralblatt fur Veterinarmedizin, 1975, B22, 480.

12 Boulter, E A, Fournal of Hygiene, 1957, 55, 502.

${ }^{13}$ McCarthy, K, Downie, A W, and Bradley, W H, fournal of Hygiene, $1958,56,466$

${ }^{14}$ Rweyamamu, M M, Johnson, R H, and Laurillard, R E, British Veterinary fournal, 1969, 125, 317 .

15 Gibbs, E P J, Johnson, R H, and Osbourne, A D, Veterinary Record, 1972, 91, 395.

${ }^{16}$ Nagington, J, Tee, G, and Smith, J S, Nature, 1965, 208, 505.

17 Gibbs, E P J, and Osbourne, A D, British Veterinary fournal, 1974, 130,150 .

18 Communicable Disease Reports, Public Health Laboratory Service, 1975 1976.

19 Marennikova, S S, et al, Acta Virologica, 1975, 19, 260.

${ }^{20}$ Muirhead, R H, Gallagher, J, and Burn, K J, Veterinary Record, 1974, 95, 552 .

\title{
Casualty departments and the monitoring of drug dependence
}

\author{
A HAMID GHODSE
}

British Medical fournal, 1977, 1, 1381-1382

\section{Summary}

In a month-long prospective survey of patients attending London casualty departments with drug-related problems, 395 drug-dependent patients were identified. $A$ check against the official Home Office index of notified addicts showed that $226(57 \%)$ were not known to the Home Office. Of 92 patients who used narcotics only $53 \%$ were known with certainty to the Home Office, and when the source of notification was checked it became clear that in at least $77 \%$ of incidents involving narcotic addicts in casualty departments the addict was not reported. Repeated research in casualty departments could play a valuable role in monitoring drug dependence and might provide information supplementary to that obtained from the specialised drug treatment clinics and other sources of notification.

\section{Introduction}

Under the Misuse of Drugs (Notification of and Supply to Addicts) Regulation 1973 a doctor is required by law to notify in writing the name, sex, date of birth, address, etc of any patient whom he considers or reasonably suspects of being

Addiction Research Unit, Institute of Psychiatry, London SE5 A HAMID GHODSE, MD; PHD, lecturer in psychiatry

addicted to controlled drugs. A hospital doctor need not notify an addict only if he, or another doctor at the same hospital, has reported the patient within the previous 12 months. In practice, most notifications are made by the staff of the specialised drug treatment clinics and the remainder are made mainly by prison staff and general practitioners.

As notification is compulsory it might be assumed that the addiction statistics are accurate insofar as they report the number of addicts known to doctors ${ }^{1}$; indeed, Lewis ${ }^{2}$ found that only four of the 98 narcotic addicts who died in 1969 and 1970 were unknown to the Home Office. The notification system has never been systematically investigated, ${ }^{3}$ however, and there are indications that many narcotic addicts may be unknown to the authorities. ${ }^{4-6}$ This question of the completeness of notification is unlikely to be finally settled by any practical study that can be devised, but any inquiry that looks at the overlap between a given special sample and the Home Office register may throw a little light on the question.

\section{Method}

A one-month prospective survey of patients with drug-related problems was carried out in 62 casualty departments in Greater London in July $1975 .^{7}$ The dependence status of all the patients in the survey was assessed by the casualty officers in terms of defined criteria laid out in written guidelines, ${ }^{8}$ and the drugs of abuse were recorded. A list of patients was obtained whom the casualty officers considered to be dependent on drugs, and, with strict regard to confidentiality, their names were checked against the official Home Office index of notified addicts.

It was not always easy to be sure that the casualty records and the Home Office information referred to one and the same person. Three criteria were used to identify addicts: name, date of birth or age, and address. If two or three out of these three variables cor- 